\title{
The effects of prenatal care on cesarean section rates in a maternity and children's hospital
}

\section{Doğum öncesi bakım hizmeti almanın sezaryen doğum üzerine etkisi}

\author{
Ayten Taşpınar, Saliha Özpınar*, Ayden Çoban, Mert Küçük
}

Department of Midwifery (Assoc. Prof. A. Taşpınar, MD, Assoc. Prof. A. Çoban, MD), Adnan Menderes University School of Health, TR-09010 Aydın, Department of Midwifery (Assist. Prof. S. Özpınar, MD), Celal Bayar University School of Health, TR-45030 Manisa, Department of Obstetrics and Gynecology (Assoc. Prof. M. Küçük, MD), Sitkı Koçman University School of Medicine, TR-48000 Muğla

\begin{abstract}
Aim. The aim of descriptive study was to determine whether women are receiving prenatal care services and if benefiting from prenatal care has an impact on the incidence of cesarean delivery. Methods. This descriptive and research was carried out at the Manisa Maternity and Children's Hospital with inpatients who had just given birth $(n=269)$. The data was collected with a questionnaire. The questionnaire consisted of two parts. The first part encompassed questions on the sociodemographic and obstetric characteristics of the women and the second part related to the prenatal care services that women received. Data was analyzed using the SPSS 15.0. Basic descriptive findings and the education provided as prenatal care services were analyzed using frequency distributions. Selected characteristics and mode of delivery were compared using qisquare analysis. Results. It was observed that $97 \%$ of the women participating in the study had received at least one prenatal care. Of the 8 women who had not received prenatal care $(3 \%)$, only one $(12.5 \%)$ had delivered by cesarean section. Cesarean rates were higher in women who received prenatal care four or more times in the pregnancy, in women who obtained the service only from doctors, in those who obtained it from private hospitals, and in women who had undergone ultrasound scanning. Moreover the study found that the education and training that comprised the content of prenatal care services were inadequate. Conclusion. According to the study quality of antenatal care prevent cesarean delivery which non-medical reasons.
\end{abstract}

Keywords: Cesarean section, delivery, Manisa, prenatal care

\section{Özet}

Amaç. Çalışma, kadınların doğum öncesi bakım hizmeti alma durumlarının tespit edilmesi ve doğum öncesi bakım hizmeti almanın sezaryen doğum sıklığı üzerine etkisini belirlemek amacıyla planlanmıştır. Yöntem. Tanımlayıcı tipteki araştırma, Sağlık Bakanlığı'na bağlı Manisa Doğum ve Çocuk Bakımevi Hastanesi Obstetri kliniğinde yatan yeni doğum yapmış annelerle yapılmıştır $(n=269)$. Veriler, araştırmacılar tarafından literatür taranarak oluşturulan soru formu ile toplanmıştır. Soru formu iki bölümden oluşmaktadır; ilk bölüm kadınların sosyodemografik ve obstetrik özellikler ve ikinci bölüm kadınların aldıkları doğum öncesi bakım hizmetleri ile ilgilidir. Çalışmada tanımlayıcı bulgular ve doğum öncesi bakım hizmetlerinde verilen eğitimler sayı ve yüzde gibi tanımlayıcı istatistikler ile ve sosyodemografik özellikler ile doğum şekilleri ki-kare analizi ile değerlendirildi. Bulgular. Çalışmada kadınların \%97'sinin doğum öncesi bakım hizmetini en az $1 \mathrm{kez}$ aldığı belirlendi. Kadınların 8'inin (\%3) doğum öncesi bakım almamış ve DÖB almayanlardan sadece 1'inin (12,5\%) sezaryenle doğum yapmıştır. Çalışmada gebeliğinde dört ve daha fazla doğum öncesi bakım hizmeti alanlarda, bu hizmeti sadece doktordan alanlarda, hizmeti sadece özel kurumlardan alanlarda ve gebeliğinde ultrasonografi çekilenlerde sezaryen oranları daha yüksek olduğu belirlenmiştir. Ayrıca çalışmada, doğum öncesi bakım hizmetlerinin içeriğini oluşturan eğitimlerin yetersiz kaldığı, kadınların doğum ve doğum şekilleri konusunda yeterli bilgi ve danışmanlık hizmeti verilmediği bulunmuştur. Sonuç. Çalışma sonuçlarına göre nitelikli doğum öncesi bakım hizmetlerinin tıbbi gerekçesi olmayan sezaryen doğumların önlenmesine önemli katkıda bulunabileceği düşünülmektedir.

Anahtar sözcükler: Doğum öncesi bakım, sezaryen doğum, doğum şekli, Manisa 
Geliş tarihi/Received: September 19, 2014; Kabul tarihi/Accepted: December 22, 2014

\section{*Corresponding author:}

Dr. Saliha Özpınar, Ebelik Bölümü, Celal Bayar Üniversitesi Tıp Fakültesi, TR-45030 Manisa. Email: salihaozpinar@gmail.com

\section{Introduction}

Prenatal care refers to the monitoring of an expectant mother and the fetus at regular intervals throughout the pregnancy with examinations and recommendations provided by qualified health professionals. The principal aim of prenatal care is to ensure that mothers experience a healthy pregnancy and that healthy babies are born [1]. Today, only $70 \%$ of women around the world are monitored by health professionals at least once during their pregnancy. This rate shows major differences according to the level of development in various countries. While in developed countries, $98 \%$ of mothers receive at least one examination during the pregnancy, in underdeveloped countries, this rate is $65 \%[2,3]$. In Turkey, a record of births in the last five years shows that while mothers receiving prenatal care services at least once from health professionals at their last pregnancy are $92 \%$ in 2008 [3]. In a study conducted in Denizli, this ratio was found as $88.5 \%$ [3].

There is a rapid rate of increase in cesarean births throughout the world [4-8]. In the World Health Report (2010) prepared by Gibbons et al. [4] on the basis of a study of cesarean rates in 137 countries, it can be seen that approximately 18.5 million cesarean deliveries occur in the world every year. It has been found that in about $40 \%$ of countries in the world, cesarean birth rates are below $10 \%$; in $10 \%$ of the countries, this rate is between $10 \%-15 \%$, and in approximately $50 \%$ of the countries, about $15 \%$. The report reveals that cesarean birth rates vary between $13.5 \%$ (Netherlands) and $38.2 \%$ (Italy) in Europe, and are at a level of $45.9 \%$ in Brazil, $17.4 \%$ in Japan, $25.9 \%$ in China [4] and $31.8 \%$ of the U.S. in2007 [9, 10]. The cesarean birth rate targeted by the World Health Organization (WHO) based on maternal andperinatal mortality rates is $5 \%-15 \%[4,7,8$, $11]$.

Over the years, Turkey has exhibited an increase in cesarean birth rates, gradually rising from $13.9 \%$ in 1998 to $37 \%$ in 2008 . If births at home are subtracted from this statistic, the rate climbs to $40.8 \%$ [4, 13]. Cesarean birth rates in Turkey exhibit differences depending on whether the birth occurred in a university-training hospital, state hospital or private hospital. Cesarean rate was found $37.7 \%$ in 2002 and $51 \%$ in 2007 in Atatürk University Faculty of Medicine Hospital [14], while it was found in 2000 as $54.1 \%$, and 41.8\% in 2010 in Uludağ University Medical Faculty Hospital [15]. In a study conducted in the city of Kahramanmaraş, cesarean rates was 34.4\% in 2004 [16] and $40.2 \%$ in 2006, while the rate of cesarean delivery in another study conducted in Taksim Education and Research Hospital in İstanbul was found $18.2 \%$ in 2000 [17], while $31.3 \%$ in 2010. In an Education and Research Hospital in İzmir average cesarean section rate was found to be $48.1 \%$ between the years 2006-2011 [18].

Although there are differences in cesarean birth rates at different types of hospitals, the figures show that cesarean birth rates have in fact increased in all hospitals [19]. While both in Turkey and around the world, many factors such as mothers' advanced age, level of education, economic issues, doctors' fear of malpractice suits, choosing this mode voluntarily over others, and the expansion of cesarean indications have contributed to the rise in cesarean rates, the frequency and quality of prenatal care services are also factors which have an impact on the incidence of cesarean births $[6,13]$. There are few studies in Turkey and abroad about the effect of receiving prenatal care on the mode of delivery. In order to reduce the incidence of cesarean births as recommended by WHO, the effects of prenatal care services have first to be studied and determined. 
The aim of the present study was to determine whether women are receiving prenatal care services and if benefiting from prenatal care has an impact on the incidence of cesarean delivery.

\section{Material and methods}

\section{Setting and sample}

This descriptive research was carried out at the Manisa MaternityandChildren'sHospitalwith inpatients who had just given birth. Manisa is located in the western Anatolian region of Turkey. It is a city that is greatly developed in terms of agriculture, trade and industry and one that harbors a large migrant population from the Eastern and Southeastern Anatolian regions. The hospital where the study took place is centrally situated and provides women with maternity care and services in gynecology, obstetrics and family planning. About five thousand births occur in this hospital in a year. Most women presenting at the hospital are from middle- and lowerincome brackets. The universe of the study included delivires performed in the hospital in 2008 (4950).

The sample size of the study was determined by the sampling method used when the universe of the study is known and the study consisted 267 female participants (with $95 \%$ confidence intervals and sampling error of 0.5). The cesarean birth rate in 2008 in the hospital where the study was conducted was $44 \%$ and based on this data, $44 \%$ participants of the study consisted of cesarean deliveries whereas $(n=117), 56 \%$ consisted normal vaginal delivery $(\mathrm{n}=150)$.

Data were collected by nonprobability sampling sample method and women who were willing to participate were accepted to the study untill the sample size has been reached. To give birth in this hospital and willing to participate in the study were the criterias for inclusion in the study.

\section{Ethical considerations}

Permission for the study was obtained from the Manisa Provincial Health Ministry and the Hospital's Chief Physician's Office. The women's informed consent was also obtained.

\section{Data measurement}

The data was collected with a questionnaire. The questionnaire consisted of two parts and a total of twenty-five questions. The first part encompassed questions on the sociodemographic and obstetric characteristics of the women, including age, education, working status, official marriage status, blood-relation marriage status, perception of income (the family's economic status as perceived by women when they compared the earnings of the working members of their family with family expenditure), family type, whether or not the pregnancy was a wanted pregnancy, number of births. The second part related to the prenatal care services that women received: the number of prenatal care sessions, the first visit for prenatal care, and the professionals from whom the service was obtained, the hospital from which it was obtained, whether or not ultrasound scans were performed, and the type of education provided as part of prenatal care services. The implementation stage of the study began by informing the inpatients who had given birth in the maternity service about the research and obtaining their consent. The data collection questionnaire was filled out by the researchers on the basis of face-to-face interviews carried out with the patients. Filling out the questionnaire took approximately 15 minutes for each patient.

\section{Statistical analysis}

Data was analyzed using the SPSS (Statistical Package for the SocialSciences). Basic descriptive findings and the education provided as prenatal care serviceswere analyzed using frequency distributions. Selectedcharacteristics and mode of delivery 
werecompared using $\mathrm{X}^{2}$ analysis. A p-level of 0.05 was considered statistically significant.

\section{Results}

Mean age of the 267 participants in the study was $26.1 \pm 5.2$ (Range: 16-42 years), mean number of pregnancies experienced was $2.1 \pm 1.3$ (Range: 1-8) and mean number of living children was $1.7 \pm 1.0$ (Range: 1-8). Selected characteristics of the women can be seen in Table 1. It was seen that as the level of education got higher, more women delivered by cesarean $(\mathrm{p}=0.00)$. It was also found that very few women were employed(n=33, 10.9\%) and of those whowere not, most gave birth by cesarean $(69.7 \%)$. It was established that more of those that were officially married $(n=114,45.6 \%)$ gave birth by cesarean. Again, $83.5 \%$ of the women were not married to blood-relatives and among those who were not, there were more $(n=105,47.1 \%)$ cases of cesarean birth $(p=0.002, p=0.040, p=0.019$, respectively). It was seen that the women's ages, the income status and the type of family they lived in had no impact on the mode of delivery ( $\mathrm{p}=0.205, \mathrm{p}=0.546$ and $\mathrm{p}=0.772$, respectively). It was seen that there was more of a percentage of those with wanted pregnancies who had had cesarean deliveries (46.8\%) $(\mathrm{p}=0.046)$. It was seen that the lower the number of times women gave birth, the higher the percentageof cesarean delivery $(\mathrm{p}=0.044)$. It was observed that $97 \%$ of the women participating in the study had received prenatal care and that only 8 women $(3 \%)$ had not had any prenatal care at all. $90.3 \%$ of the women $(n=241)$ were seen to have benefited from prenatal care four times and more. Of the 8 women who had not received prenatal care (3\%), only one (12.5\%) had delivered by cesarean section. As the number of women receiving prenatal care increased, percentages of cesarean delivery also increased $(\mathrm{p}=0.026)$. Only a small percentage of the women $(\mathrm{n}=26,9.7 \%)$ made their first visit to the hospital for prenatal care within the first four months of their pregnancy but it was found that the month of the first visit did not affect the mode of delivery $(\mathrm{p}=0.051)$. It was observed that most of the women under the prenatal supervision of only a doctor (63\%) had delivered by cesarean and that the least percentage of women delivering by cesarean $(22.7 \%)$ came from the group of women who were under the control of midwives and/or nurses. This too was a statistically significant finding $(\mathrm{p}=0.003)$. Of the women, $44.9 \%$ received prenatal care services only from state institutions. A similar percentage of women (43.8\%) received prenatal care from both state and private institutions (e.g., Family Planning Centers, Mother-Child Health - Family Planning Centers, Obstetrics and Children's Polyclinics). It was found however that, compared to women obtaining services from state institutions, the rate of cesarean delivery was higher in women who received prenatal care at private hospitals $(68.2 \%)$ and from both state and private institutions $(53 \%)(\mathrm{p}=0.000)$. It was found that there was a higher percentage of women delivering by cesarean (45.6\%) in those women who did have ultrasound scans $(\mathrm{p}=0.020)$, (Table 1).

When women were asked whether they had been given education as part of the prenatal care provided, $37.8 \%$ said they had received no information on the danger signals in pregnancy, $37.1 \%$ said they had received no information on hygiene, $44 \%$ revealed that they were not educated in sexuality during pregnancy, $27.8 \%$ complained of not being provided information about immunization, $22.8 \%$ said they were given no knowledge about nutrition in pregnancy, 39.8\% said they had been told nothing about actual delivery, $41.3 \%$ said they had had no breastfeeding education and $66 \%$ stated that they had not been given information on the birth control methods they could use after the delivery (Table 2). 
Table 1. Some demographic characteristics of the women and a comparison of the status of receiving prenatal care and modes of delivery.

\begin{tabular}{|c|c|c|c|c|}
\hline Characteristics & $\begin{array}{l}\text { Normal vaginal } \\
\text { childbirth }(n=150)\end{array}$ & $\begin{array}{l}\text { Childbirth by cesarean } \\
\text { section }(n=117)\end{array}$ & Total $(n=267)$ & $\mathbf{p}$ \\
\hline \multicolumn{5}{|l|}{ Mother's age at childbirth (years) } \\
\hline$<20$ & $15(75.0)$ & $5(25.0)$ & $20(7.5)$ & \multirow{3}{*}{$\begin{array}{l}\mathrm{X}^{2}=3.168 \\
\mathrm{p}=0.205\end{array}$} \\
\hline $20-34$ & $123(54.4)$ & $103(45.6)$ & $226(84.6)$ & \\
\hline $35-49$ & $12(57.1$ & $9(42.9)$ & $21(7.9)$ & \\
\hline \multicolumn{5}{|l|}{ Level of education } \\
\hline No education/elementary school drop-out & $30(83.3)$ & $6(16.7)$ & $36(13.5)$ & \multirow{3}{*}{$\begin{array}{l}X^{2}=15.312 \\
p=0.000\end{array}$} \\
\hline Elementary/middle school graduate & $87(55.8)$ & $69(44.2)$ & $156(58.4)$ & \\
\hline High school graduate or over & $33(44.0)$ & $42(56.0)$ & $75(28.1)$ & \\
\hline \multicolumn{5}{|l|}{ Working status } \\
\hline Working & $10(31.3)$ & $23(69.7)$ & $33(10.9)$ & \multirow{2}{*}{$\begin{array}{l}X^{2}=10.242 \\
p=0.002\end{array}$} \\
\hline Not working & $140(59.8)$ & $94(40.2)$ & $234(88.1)$ & \\
\hline \multicolumn{4}{|l|}{ Officially married } & \multirow{3}{*}{$\begin{array}{l}X^{2}=5.052 \\
p=0.040\end{array}$} \\
\hline Yes & $136(54.4)$ & $114(45.6)$ & $250(93.6)$ & \\
\hline No & $14(82.4)$ & $3(17.6)$ & $17(6.4)$ & \\
\hline \multicolumn{5}{|l|}{ Marriage with blood relation } \\
\hline Yes & $32(72.7)$ & $12(27.3)$ & $44(16.5)$ & \multirow{2}{*}{$\begin{array}{l}X^{2}=5.860 \\
p=0.019\end{array}$} \\
\hline No & $118(52.9)$ & $105(47.1)$ & $223(83.5)$ & \\
\hline \multicolumn{5}{|l|}{ Perceived income } \\
\hline Income less than expenditure & $47(54.0)$ & $40(46.0)$ & $87(32.6)$ & \multirow{3}{*}{$\begin{array}{l}\mathrm{X}^{2}=1.210 \\
\mathrm{p}=0.546\end{array}$} \\
\hline Income equal to expenditure & $84(55.6)$ & $67(44.4)$ & $151(56.5)$ & \\
\hline Income more than expenditure & $19(65.5)$ & $10(34.5)$ & $29(10.9)$ & \\
\hline \multicolumn{5}{|l|}{ Family type } \\
\hline Nuclear family & $116(56.9)$ & $88(43.1)$ & $204(76.4)$ & \multirow{2}{*}{$\begin{array}{l}X^{2}=0.164 \\
p=0.772\end{array}$} \\
\hline Expanded family & $34(54.0)$ & $29(46.0)$ & $63(23.6)$ & \\
\hline \multicolumn{5}{|l|}{ Wanted pregnancy? } \\
\hline Yes & $115(53.2)$ & $101(46.8)$ & $216(81.3)$ & \multirow{2}{*}{$\begin{array}{l}X^{2}=3.968 \\
p=0.046\end{array}$} \\
\hline No & $35(68.6)$ & $16(31.4)$ & $51(18.7)$ & \\
\hline \multicolumn{5}{|l|}{ Number of births } \\
\hline 1 & $67(52.8)$ & $60(47.2)$ & $127(47.6)$ & \multirow{3}{*}{$\begin{array}{l}\mathrm{X}^{2}=6.270 \\
\mathrm{p}=0.044\end{array}$} \\
\hline $2-3$ & $70(56.0)$ & $55(44.0)$ & $125(46.8)$ & \\
\hline $4+$ & $13(86.7)$ & $2(13.3)$ & $15(5.6)$ & \\
\hline \multicolumn{5}{|l|}{ Number of prenatal care exams } \\
\hline None & $7(87.5)$ & $60(47.2)$ & $127(47.6)$ & \multirow{3}{*}{$\begin{array}{l}X^{2}=6.270 \\
p=0.044\end{array}$} \\
\hline 1-3 times & $14(77.8)$ & $55(44.0)$ & $125(46.8)$ & \\
\hline 4 times or more & $129(53.5)$ & $2(13.3)$ & $15(5.6)$ & \\
\hline \multicolumn{5}{|l|}{$\begin{array}{l}\text { Health professionals from whom } \\
\text { prenatal care was obtained }\end{array}$} \\
\hline Never obtained & $7(87.5)$ & $1(12.5)$ & $8(3.0)$ & \multirow{4}{*}{$\begin{array}{l}X^{2}=14.130 \\
p=0.003\end{array}$} \\
\hline Doctor & $17(37.0)$ & $29(63.0)$ & $46(17.2)$ & \\
\hline Midwife/nurse & $17(77.3)$ & $5(22.7)$ & $22(8.3)$ & \\
\hline Drand midwife/nurse & $109(57.1)$ & $82(42.9)$ & $191(71.5)$ & \\
\hline $\begin{array}{l}\text { Institution from which prenatal care } \\
\text { was received }\end{array}$ & & & & \\
\hline Never received & $7(87.5)$ & $1(12.5)$ & $8(3.0)$ & $X^{2}=18.739$ \\
\hline Private & $7(31.8)$ & $15(68.2)$ & $22(8.3)$ & $\mathrm{p}=0.000$ \\
\hline State & $81(67.5)$ & $39(32.5)$ & $120(44.9)$ & \\
\hline State and private & $55(47.0)$ & $62(53.0)$ & $117(43.8)$ & \\
\hline Ultrasonogram & & & & \\
\hline Taken & $136(54.4)$ & $114(45.6)$ & $250(93.6)$ & $X^{2}=5.052$ \\
\hline Not taken & $14(82.4)$ & $3(17.6)$ & $17(6.4)$ & $\mathrm{p}=0.020$ \\
\hline
\end{tabular}

Table 2. Distribution of topics of education women are offered as a part of prenatal care services $(\mathbf{n}=\mathbf{2 5 9})$.

\begin{tabular}{lllll}
\hline Topics of prenatal care education & Yes & \multicolumn{2}{c}{ No } \\
\cline { 2 - 5 } & Number & \% & Number & \% \\
\hline Were you informed about danger signals in pregnancy? & 161 & 62.2 & 98 & 37.8 \\
Were you given information about hygiene in pregnancy? & 163 & 62.9 & 96 & 37.1 \\
Were you given information about sexuality in pregnancy? & 145 & 56.0 & 114 & 44.0 \\
Were you given information about immunization in pregnancy? & 187 & 72.2 & 72 & 27.8 \\
Were you informed about nutrition? & 200 & 77.2 & 59 & 22.8 \\
Were you informed about childbirth? & 156 & 60.2 & 103 & 39.8 \\
Were you informed about breastfeeding? & 152 & 58.7 & 107 & 41.3 \\
Were you informed about contraceptive methods you could use after the birth? 88 & 34.0 & 171 & 66.0 \\
\hline
\end{tabular}




\section{Discussion}

Our study shows that some sociodemographic and obstetric characteristics of women have an impact on cesarean rates. While cesarean rates were higher in more educated, working, officially married, voluntarily pregnant women, the women's being a partner in a marriage with a blood relation and having had more children results in lower cesarean rates. In many studies, it has been shown that, of the sociodemographic factors that have an effect on the cesarean rate, the age of the mother and her level of education are the ones that have the most impact $[4,6,7,11,20]$. In the present study, while it was seen that the higher the mother's education, the higher the cesarean delivery rate, a correlation was not found between the cesarean rate and the age of the mother.

The total number of times women receive prenatal care is an important indication that is useful in evaluating the adequacy of the services provided. It is reported that the WHO recommendation of at least four follow-ups of quality prenatal care for pregnant women with no pregnancy-related complaints and/or who have been recognized by health professionals as not being at risk, which is guidance that has been accepted by the Ministry of Health, reduces the number and severity of potential problems in pregnancy, delivery and after the baby is born [21]. It was seen in the present study that almost all of the women had received prenatal care at least once and only 8 women had never received any at all. A large majority of the women were seen to have benefited from prenatal care services four or more times. According to Turkey Demographic and Health Survey (TDHS) data for 2008, it is reported that in the last five years leading up to the date of the report, $92 \%$ of women in Turkey had received prenatal care at least once in the pregnancy culminating in their last live birth, $7.8 \%$ had never received prenatal care and $73.7 \%$ said that they had been monitored 4 or more times [4]. 88.3\% of women in Manisa at the time of another study in 2005 had received prenatal care at least once, $66.4 \%$ had been monitored 4 or more times, and $10.9 \%$ had never had any prenatal care at al. [22]. In our study, the rate of women receiving prenatal care at least once is higher than the rate in Turkey.

In the present study, while it was seen that only one woman out of the 8 women who never received any prenatal care had delivered by cesarean, it was observed that the more times women were monitored, the rate of cesarean births rates increased. Studies are inconsistent about what impact receiving prenatal care and monitoring have on the incidence of cesarean deliveries. TDHS 2008 data showed that as the number of times women receive prenatal care increased, cesarean percentages rose and that half of the women $(50.7 \%)$ who benefited from 6 or more monitoring sessions gave birth by cesarean section [13]. Similar findings were reported in the study by Koç [7], but Gözükara et al. [9] stated in their study that no correlation could be found between mode of delivery and having regular check-ups during pregnancy. In a study carried out in China, it was reported that there was a higher percentage of women delivering by cesarean among those who gave birth in a hospital but had not received formal antenatal care [23]. The data for the present study showed that frequency of cesarean births increases as the number of cases receiving prenatal care rose.

As much as the number of cases receiving prenatal care is important, where and from whom the care has been received are also of significance. It was found that women who received prenatal care only from doctors had a high rate of cesarean delivery, whereas women who stated that they received the prenatal care from midwives and/or nurses displayed a lower rate. Again, it was seen in our study, it was only in the private institutions that women who received prenatal care had higher cesarean rates and the cesarean rate is lower in women who received care only in the state hospitals. Although the cesarean rates of women receiving service from midwives and/or nurses and women who received care only in the state hospitals are lower, these rates are still a considerably $15 \%$ higher than the WHO recommendation. In a nation-wide study by Gözükara et al. [9], in which $79.6 \%$ of the deliveries were based on doctor's decisions and the cesarean 
birth rate was $27.8 \%$, it is interesting to note that $58 \%$ of the women had received prenatal care from doctors [24] and that in the TDHS 2008 data as well, a large majority $(89.5 \%)$ received prenatal care prenatal care from doctors [4]. Studies have shown that among the factors that may have an impact on the decision in favor of a cesarean section are doctors' personal beliefs that compared to a vaginal birth, they will be less likely to risk being confronted with medico-legal issues concerning the health of the mother or child. Also a possible factor to consider is the capability cesarean section provides in planning the birth for a desired time. Still another factor may be that, in the face of the lack of tolerance among the general population when complications arise during delivery, doctors prefer a cesarean birth simply to avoid malpractice suits $[12,19,20,25,26]$. In addition, the fact that patients at risk are more likely to seek prenatal care may also have contributed to our finding a higher incidence of cesarean in this population. It has been stated that health professionals find it easier to decide upon a mode of delivery in the case of a woman who has received quality care, monitoring, education and consulting services from the preconceptual up to the postpartum stage and that, in fact, quality and qualified service have a positive impact on reducing cesarean rates [6, 20, 26, 27].

Comprehensive studies have proved that women who receive quality prenatal care from midwives through the course of the pregnancy are admitted to hospitals during the antenatal period at a lesser rate, have less of a need for labor induction, are administered less analgesics and anesthesia during the birth, and that in the case of these women, there is an increase in spontaneous birth rates and a decrease in cesarean deliveries [6, 28, 29].

In the present study, it was found that women who have had ultrasonogram taken at least once during the pregnancy were almost half delivered their babies by cesarean. In a study carried out in China, it was reported that the rate of cesarean births in women who have had ultrasonogram taken at least once as part of their antenatal care is 1.6 times higher than in mothers who have not had ultrasound exams during the pregnancy [23].

The content of the check-up is as important in prenatal care as the number of times a patient is monitored. A look into the education given to women as part of prenatal care shows that women are mostly provided information about danger signals in pregnancy, hygiene, sexuality, immunization, nutrition, birth, breastfeeding and contraceptive methods for after the delivery. It was found however that the service provided was inadequate and did not reach all pregnant women. In particular, it was observed that only 60.2 percent of the study participants had received education on the topics that would help them to make a decision on the mode of delivery or about subjects concerning childbirth and delivery that they were most fearful or curious about [1, 30].

In conclusions; it was found in the research that almost the entire study population had received prenatal care and that a large majority of the women had benefited from these services four or more times. It was furthermore found that although the number of prenatal care sessions was high, the content of the education provided as part of the service was inadequate. It might also be recommended that more studies be carried out to explore the quality of existing prenatal care and the impact quality and frequency of prenatal services have on cesarean delivery rates.

\section{References}

1. Özvarış SB, Akın A. Access to prenatal care in Turkey. http://www.huksam.hacettepe.edu.tr/yayinursag.html. Accessed: 07.09.2011.

2. Maternal Care: http://www.unicef.org. Accessed: 29.01.2011.

3. Turan T, Ceylan SS, Teyikçi S. Influencing factors and situation of the mothers to take regular prenatal care. Fırat Sağlık Hizmetleri Dergisi 2008; 3: 157-72.

4. Hacettepe University Institute of Population Studies, (HUIPS). Turkish Demographic and Health Survey 2008. Ankara: Hacettepe University Institute of Population Studies, Ministry of Health General Directorate of Mother and Child Health and Family Planning, State Plannig Organization and TUBITAK 2009. 
5. Gibbons L, Belizán JM, Lauer JA, Betrán AP, Merialdi M, Althabe F. The global numbers and costs of additionally needed and unnecessary caesarean sections performed per year: Overuse as a barrier to universal coverage. http://www.who.int/healthsystems/topics/financing/healthreport/30Csectioncosts.pdf. Accesed: 29.01.2011.

6. Sayıner FD, Özerdoğan N, Giray S, Özdemir E, Savcı A. Identifying the woman`s choice of delivery method and the factors that affect them. Perinatal Journal 2009; 17: 104-12.

7. Koç I. Increased cesarean section rates in Turkey. Eur J Contracept Reprod Health Care 2003; 8: 1-10.

8. Monitoring Emergency Obstetric Care: A handbook. World Health Organization 2009 ISBN 9789241547734.

9. Gözükara F, Eroğlu K. Factors that affect the choices of primipars on the mode of delivery. Hacettepe University Faculty of Health Sciences Nursing Journal 2008; 15: $32-46$.

10. Cesarean Section. http://www.childbirthconnection.org/article.asp?ck=10456 Accesed: 29.01.2011.

11. Menacker F, Hamilton BE. Recent trends in cesarean delivery in the United States. NCHS Data Brief 2010; 35.

12. Guide to the management of birth and cesarean section. http://saglik.gov.tr Aaccesed: 29.03.2011.

13. Seçkiner PC, Tezcan S. Turkey's rising trend in caesarean section: Who are these women? European population Conference 2010, 1-4 September, Austria (extended abstract). http://epc2010.princeton.edu. Accessed: 29.01.2011.

14. Yılmaz M, İsaoğlu Ü, Kadanalı S. Investigation of the cesarean section cases in our clinic between 2002 and 2007. Marmara Medical Journal 2009; 22: 104-10.

15. Demir BÇ, Ocakoğlu G, Özerkan K, Orhan A, Cengiz C. Cesarean delivery rates and changing indications in our clinic between 2000-10. Uludağ Üniversitesi Tıp Fakültesi Dergisi 2012; 38: 123-7.

16. Coşkun A, Köstü B, Ercan Ö, Kıran H, Güven MA, Kıran G. The comparison of deliveries in the center of Kahramanmaraş in 2004 and 2006. TJOD Dergisi 2007; 4: 168-72.

17. Yumru AE, Dinçgez B, Öndeş B, Atalay N. The relation between gender of babies, macrosomia and cesarean ratio in 11561 deliveries in our clinic. JAREM 2011; 1: 18-20.

18. Töz E, Kurt S, Canda MT, Gürbüz T, Taşyurt A. Five year birth statistics and cesarean indications in Izmir Ege Doğumevi ve Kadın Hastalıkları Eğitim ve Araştırma Hastanesi. Tepecik Eğit Hast Derg 2011; 21: 109-12.

19. Şahin NH. Rates and outcomes of cesarean section. M.U. Nursing Science and Art Journal 2009; 2: 93-8.

20. Hopkins K, Amaral E. The role of nonclinical factors in cesarean section rates in Brazil. Population Association of America 2005 Annual Meeting Program (extended abstract). http://paa2005.princeton.edu. Accesed: 12.11.2011.

21. Prenatal care management Ministry of Health Protocol 02-VI. http://www.saglik.gov.tr/TR/belge/1-6077/eski2yeni.html (accesed: 27.03.2011).

22. Manisa Demographic and Health Survey 2005. Celal Bayar University Medical School, Department of Public Health, Manisa. June 2007: 61-8.

23. Sufang G, Padmadas SS., Fengmin Z, Brown JJ, Stones RW. Delivery settings and caesarean section rates in China. Bulletin of the World Health Organization 2007; 85: 733-820.

24. Çalışkan ZS. The effect of mothers' receiving prenatal care on birth types and newborn health. T. C. Marmara Üniversitesi Eğitim Bilimleri Enstitüsü Eğitim Bilimleri Anabilim Dalı Halk Eğitimi Bilim Dalı YayınlanmamışYüksek Lisans Tezi. Istanbul 2006.

25. Park CS, Yeoum SG, Choi ES. Study of subjectivity in the perception of cesarean 
birth. Nursing and Health Sciences 2005: 3-8.

26. Gamble JA, Creedy DK, McCourt C, Weaver J, Beake S. A critique of the literature on women's request for cesarean section. Birth 2007; 34: 331-40.

27. Arslan H, Karahan N, Çam C. Nature of midwifery and effects on delivery mode. M.U. Nursing Science and Art Journal 2008; 1: 54-9.

28. Leslie SM, Storton S. The coalition for improving maternity services: Evidence basis for the ten steps of mother-friendly care step one. The Journal of Perinatal Education 2007: 16; 10-9.

29. Gamble JA, Creedy DK. Women's request for a cesarean section: A critique of the literature. Birth 2000; 27: 256-63.

30. Spinelli A, Baglio G, Donati S, Grandolfo ME, Osborn J. Do antenatal classes benefit the mother and her baby? J Matern Fetal Neonatal Med 2003; 13: 94-101. 